\title{
THE PLACE AND THE ROLE OF St. CYRIL AND St. METHODIUS IN SLAVIC UNDERSTANDING AND ACCEPTANCE OF THE CHRISTIAN ETHICAL VALUES
}

\begin{abstract}
Most of the moral philosophers are teachers, educators, saints of the illuminating word and deeds. Among them, two names do accentuate, the first one is Saint Cyril of Thessalonica (also known as Constantine the Philosopher) and the second one is Saint Methodius.

They were not simply teachers of the illiterate, but they have sought to advance people - on those who have been on the edge of civilization to reveal the secrets of the spirit and mind, to help maladapted to get trained, the ignorant to be enable to be literate and to learn the secrets of life.

That what true teachers are -enlighteners, and the wise thank them for these divine benefits.
\end{abstract}

Keywords: ETHICS, EVIL, GOD, EDUCATION

\section{Introduction}

Most of the moral philosophers are teachers, educators, saints of the illuminating word and deeds because they were guided by the idea that teaching, upbringing and educating people is an important cultural and ethical achievement. Among them, two names do accentuate, and the first one is Saint Cyril of Thessalonica (also known as Constantine the Philosopher) and the second one is his older brother Saint Methodius, both being Byzantine missionaries "brought up in the upper class of the Byzantine social hierarchy, the carriers of the affirmation of the Slavic spiritual and cultural tradition, which as Slavic teachers were in service of the Byzantine political and military interests" (Велев, 2005, 209). ${ }^{1}$

\footnotetext{
${ }^{1}$ Historical compliance of the time in which they lived confirm another truth, liberated from the canonical cliché of the hagiographic model of rewriting personal biographies, i.e. that they were not of Slavic origin, but probably descendants of the old indigenous Macedonian population that knew the Slavic language and which lived together with the other nations in Byzantium and with the Slavic nations. Therefore, the Byzantine court has used them as intermediaries to impose political and spiritual faith over Slavic people. This conclusion is based on the authenticity of the old chron-
} 
Truly to understand who are Saint Cyril and Saint Methodius and what is their historical role and the role of their ethics in the foundation and the development of the universality of the ethical values and the axiology system derived from it, one should primarily mention the preconditions for what they have grown into, i.e. their life journey and specific events and activities.

Cyril of Thessalonica, also known under the name of Constantine the Philosopher, has a life story of a devoted scholar. Born in the year of 827 in Thessalonica, which at the time was "one of the important centres of the former Byzantine Empire, in the house of Leo, a highly ranked dignitary who occupied high position in the state civil service: he was an assistant military commander of the Thessalonica district, and mother Maria, a woman who came from a worthy and dignified family, also known in the imperial court in Constantinople" (Поленаковиќ, 1985, 12-13).

The unique features and skills of Constantine are mentioned in Cyril's Hagiography in which it is said that Constantine already at the early age of seven has chosen or determined his life commitment - philosophy. In confirmation of this commitment, Constantine narrates a dream he had in which he has been offered out of many girls to choose one for his life companion. Out of all the girls gathered, he chose one that was "the most beautiful of all, with bright face, elegantly decorated with gold necklaces and pearls and other jewellery. Her name was Sofia i.e. Wisdom" (Миловска \& Таковски, 1996, 27) - Divine Wisdom, beautiful form of the Spirit - philosophy.

In accordance with the state positions held by his father, Constantine had the very best education, in the world's political and cultural centre of Constantinople, studying from the greatest scientists like Photios - dialectics and philosophical sciences as well as Leo the Mathematician - with whom he studied about Homer and geometry. "He proved and distinguished himself in all branches of the science, especially in the most difficult one - Logic and achieved the highest success" (Поленаковиќ, 1985, 17-18). After completing the then famous Magnaura School, he was appointed as a librarian in the library of the Constantinople Patriarchate, "followed by an appointment of an associate and teacher, i.e. to teach philosophy in the Magnaura School" (Миловска \& Таковски, 1996, 31).

icles, and on the contents of the famous Pannonian legends - extensive Biographies of St. Cyril and St. Methodius. The Slavic tribes who have inhabited the region of Macedonia and already grew into the dominant population primarily lived in closed communities isolated from the indigenous Macedonian population. But the indigenous Macedonian population having a need to establish direct trade contacts with Slavic communities, considering they were good craftsmen and farmers and had to exchange goods and weapons with them, came in a position to become bilingual, to know the Slavic speech too. 
This is the period of his life when the nickname "The Philosopher" (Constantine the Philosopher) originates. He was also called the "the wise one", as well as "a prime teacher". He had a good and pure soul, he was clever, gentle, calm and temperate. He was offered to marry the richest girl and to become a kniaz (Миловска\&Таковски, 1996, 30), but for him there was nothing more precious than learning, the true place where he was looking for real honour and wealth, "which is why he never gave up on his committed dedication to spirituality" (Поленаковиќ, 1985, 239). Once during an apparition, he saw the moment of his departure from his earthly life, so he put on a ceremonial clothing and said that his spirit is up and joyful because he saw his entering in the house of the Lord: "From this point on, I am no longer a servant to the king, nor to anyone on this earth, but only to God Almighty. I was not and I was, and I am in eternity, Amen" (Миловска\&Таковски, 1996, 66). The very next day, he dressed himself in a monastic habit, became a monk and took the name of Cyril.

Near the end of his life, he ill-suffered for 50 days and on his death bed, he left a legacy for his brother Methodius, saying: "Well brother, we were two souls yoked to plow one trench, but I fall on the field, having finished my part. I do know that you adore the mountain (i.e. the monastery), but don't leave the teaching for the sake of the mountain, because through teaching you can be saved" (Миловска\&Таковски, 1996, 77). Before his death on February 14, the year of 869 (old style) "he prayed to God to reach and protect the flock which he has entrusted him, to redeem his disciples and devotees from all evil and sacrilege, to make honest people out of them, to preserve those who diligently make good deeds and what pleases God, as what he did himself" (Панонски легенди, 1987, 77-78). The Pope ordered a glorious funeral in the church of St. Clement of Rome, to lay to rest the relics brought by Methodius. All Slavic nations have posted boards on his grave in gratitude of his teaching understood as enlightenment work.

The elder brother Methodius, born between 810-820 year as the eldest son of Leo and Maria, was also a brilliant person, a law graduate from Constantinople. Even from early age, he held high state and church positions, i.e. "since young age, he was appointed by the Byzantine court to military and administratively govern the principality ${ }^{2}$ as a kniaz, serving for a period of 10 years, i.e. between the year of 845 and 855" (Поленаковиќ, 1985, 14-15). Political defeat later on in life forced him to abandon his sacred career and family, "becoming a monk in the monastery of Polihron in Olympus - Little Asia, putting on his monastic habit and receiving the name of Methodius" (Панонски легенди, 1987, 69).

\footnotetext{
${ }^{2}$ His principality was situated north of the city of Thessaloniki - along the lower course of the river Struma and Bregalnica (in the region of Strumica-Bregalnica).
} 
Together with his brother Cyril, they had the honour to lead the most difficult cultural mission of the epoch - the literacy of the Slavic people, together joined with faith to be readied for the great cultural task of understanding the Christianity and its exceptional ethical values. Cyril invented a new Slavic alphabet and translated into Slavic the first books, among which the Bible. Both he and his brother, along with the books, set off to Moravia, where they taught and educated the people so well, so these regions up till date still celebrate and glorify them as their spiritual fathers.

\section{Cultural and philosophical premises for the general European significance of their work}

Their monumental work, as well as the work of their students and followers, up till date was largely summarized and conceived by science through the synthetically derived generally known trias:

- they are the founders of the first Slavic alphabet;

- they made the first translations of the church books from the then reigning Greek language into Slavic language;

- they are the initiators of the educational and religious work among the Slavic nations.

Even though these are the central aspects, the pivotal points of their initiatives and efforts, "if we limit ourselves to them in the interpretation of the work of these people, we will not go beyond the general statements and conclusions that have been offered up till date" (Поповски, 1989, 133). As Popovski further pointed out very well, the conclusion is that we will not be able to come to or draw in its finest form, the conclusion of the general European significance and importance of their work which is based primarily on several cultural and philosophical premises out of which, for the purposes of this paper, I will single out just three of them, and point out only the last one, according to my field of knowledge and expertise:

1. Against the established trilingual thesis for the interpretation of God, what Cyril and Methodius are offering is "equality of languages - equality of nations, i.e. a premise that stems from the very essence of the Christian ideology" (Muck \& Adeney, 2009, 114), which in their case is taken as the basic pragmatic objective in the teaching.

2. Humanism through the diplomatic function of Cyril and Methodius.

3. The honour to lead the most difficult mission of the epoch - the literacy of the Slavic nations, which joined with the faith are to be readied for the great cultural task of understanding the Christianity and its exceptional ethical values. ${ }^{3}$

\footnotetext{
${ }^{3}$ A study of the Christian philosophy as understood in ninth-century Byzantine theology is made on the bases of an utterance of Saint Constantine-Cyril by Ihor Ševčenko, "The Definition of Philosophy in the Life of Saint Constantine [Cyril]", in the vol-
} 
Namely, Cyril was the first one to offer, in Slavic language, a definiteon of the philosophy, while stressing its ethical dimension: "Philosophy is the understanding of God's and of human's essence for a person to be closer to God. It teaches the person that his deeds are the image and reflection of the One who created him" (Панонски легенди, 1969, 29). This only confirms that the love towards wisdom is in service of the proper and right human act! Because of this, people should use the mind and the knowledge in order to distinguish themselves in their actions, which means that by acting ethically they would become similar to the divinity which has created them to do good, and not evil and trouble in the world, which later on St. Clement of Ohrid will incarnate in his categorical imperative: "It is not enough just to run away from evil, but also to do good!" (Климент Охридски, 1996, 110, as well as 151).

In this context, Cyril relates the human being and his thought with the Divine Being as a real source of logic and ethics. Defining the thesis to the very end that the individual aspiration towards the good is the most noble and grand deed, i.e. aspiring with respect to the similarity with the good Lord, Cyril steers the human intellectual and moral strength to seek and find what is truly good and thus being the lead for the man towards the executeon of such good. The good is not unclear, but determined and certain. People have the right form.

With this, Cyril pointed out that the individual aspiration towards good is the noblest one, towards similarity with the good Lord. As written after the persecution of the human from Heaven and the condemnation to death: "God did not completely abandon the human, but with his great mercy and love, each year and over time shows to the humanity the deeds and achievements of a few chosen people as an example for all to steer towards the good" (Панонски легенди, 1969, 68). The logical consequence is that the one who knows, will do good, which means that, according to them, there is no difference between the awareness for the good and the good deed. As Temkov points out, this is similar to his "civilization work, which gave light and sight to the people, to see and to learn of good" (Темков, 2003).

This understanding of his of the world, the relationship between God and the human through the ethical conduct, where the human can be an image and manifestation and also reflection of the One who created him, is the basis of the efforts of his older brother Methodius, because "faith without deeds is dead and those who think to know God shall fall out, while their deeds will steer away from Him" (Панонски легенди, 1969, 74). This means that the virtuous devotee Methodius has only one ethical task "to serve everyone with all deeds (i.e. serving everyone with his good deeds), to entice

ume, For Roman Jakobson: Essays on the Occasion of His Sixtieth Birthday, 11 October, 1956, comp. Morris Halle, Horace G. Lunt, Hugh McLean, and Cornelis H. Van Schooneveld, The Hague, 1956, pp. 449-57. 
everyone" (Панонски легенди, 1969, 71) because "what is the benefit for the human when gaining the whole world, while emptying or losing his soul? What can a man get in exchange for his soul?" (Климент Охридски, 1996, 33). According to the Panonic legends, "to ones he was equal, to some slightly smaller, while to others greater than them, surpassing ones through deeds, others through the word i.e. (ones with humbleness and silence, others even more through fasting and vigil, as well as with prayer and calmness)" (Климент Охридски, 1996, 33).

Among other things, Methodius is also an author of the first philosophical texts created in Slavic language following the belief that by writing philosophy in Slavic language at the same time defends "the right of the Slavic nations to cultural autonomy and identity" (Tachiaos, 2001, 77). Moreover, Methodius wrote and gave the Slavic nations the first legal paper Law on how to judge the people, a text which has introduced the modern Byzantine Christian ethics and other life rules and principles, a work full of advice on the just and righteous relations between people, which means a book that is as legal as it is ethical.

Later on with his students (the Seven Ones: Cyril, Methodius, Clement, Naum, Angelariy, Sava and Gorazd), Methodius has gone through an extremely difficult path of teaching and enlightenment, especially in Pannonia and Slovakia under conditions of hostile behaviour and constant attacks. His strong spirit was not breakable even by the imprisonment in Bavaria, neither by the numerous tortures nor by the constant attacks from the German priests. He persistently continued on with his work, spreading Christianity in the Slavic language in Moravia and Pannonia, brining literacy to many students, for which he deservedly received the title Archbishop of the Pannonian church.

He died in the year of 885, appointing Gorazd as his deputy, one of his students, which all escaped the death threats by swimming across the Danube river into the then Bulgarian Empire. Clement and Naum arrived in Ohrid and with their deeds and works as well as with the founding of the Ohrid School, they developed the ideas and the teachings of the Slavic teachers St. Cyril and St. Methodius.

\section{Instead of a conclusion}

A milestone in the cultural as well as in the historical development of all Slavic nations is the work of the Byzantine missionaries Cyril and Methodius - creating the Slavic alphabet, ${ }^{4}$ the creation of the first Slavic literary

\footnotetext{
${ }^{4}$ For the purpose of spreading the religious service in Slavic language, the first Slavic alphabet was created - the Glagolitsa. Constantine, with the help of Methodius in 862 creates the first alphabet - Glagolitic alphabet, consisting of 38 letters, out of
} 
language and the translation of the much needed liturgical books from Byzantine into Slavic language as well as the introduction of the Slavic language into the religious service. If to all of this one adds the founding, the existence and the work of the group of enthusiastic students and followers of the Slavic teaching and religious service, then it will very easy see where is the basis of the independent Slavic teaching, literature and religious service, understood as a cultural and ethical task in the broadest sense of the word!

Ever since this historical moment, more than twelve centuries ago, it can be considered that the Slavic nations, or as they were called by the first Slavic writers - "the Slavic tribe", entered the circle of cultural nations of Europe, offering a new form of literacy, as well as a new form of ethics. Specifically, as noted by Giorgio Nurigiani in his work Macedonian geniuses over the centuries, "in the history of civilization, there are very few achievements alike those of the brothers St. Cyril and St. Methodius, in whose missions we can find the first signs of the Macedonian culture. Their outstanding work has introduced the Slavic nations into the world of culture and has raised them to the level of civilized people" (Nurigiani, 1972, 16).

This is so because the work of Cyril and Methodius was not accepted only in the context of developing the idea of linguistic and national equality, as well as the idea of Slavic origin, ${ }^{5}$ but also as a moral virtue and moral testament. The confirmation and evidence for this can be found within their work as practical carriers of the universal ethical-philosophical idea (Свидлер \& Мојзес, 2005, 22) - providing knowledge (on the road to the acceptance of God in itself, for itself and by itself), every human soul can go back to himself as a person! For these very reasons, "they were not just teaching the illiterate, but sought to elevate and extol people to discover the secrets of the spirit and the mind, to enable them, to make them literate and to help them discover the secrets of life and the very living" (Минчева-Коцевска, 2009, 42). For devoting to the goal of enlightenment of the people - Cyril and Methodius of Thessalonica are saints of the spirit and kindness. In fact, after all, "the ethics itself means commitment to ascent or enlighten people" (Темков, 2003).

which 24 following the example of the Greek alphabet, while 14 letters were invented by Constantine to fit certain voices of the Slavic language.

${ }^{5}$ In other words, as a kind of linguistic innovation and cultural benefit. 


\section{References}

Dvornik, F. (1956). The Slavs: Their Early History and Civilization. Boston: American Academy of Arts and Sciences.

Климент Охридски. (1996). Похвали и поуки. Скопје: Табернакул.

Meschonnic, H. (2011). Ethics and Politics of Translating. Philadelphia: John Benjamins Publishing Co.

Миловска, Д. и Ј. Таковски. (1996). Македонски житија IX-XVIII век. Скопје: Табернакул.

Минчева-Коцевска, Б. (2009). Универзална етика. Скопје: Макавеј.

Muck, T.\&F. S. Adeney. (2009). Christianity Encountering World Religions: The Practice of Mission in the Twenty-First Century. Grand Rapids, MI: Baker Academic.

Nurigiani, G. (1972). The macedonian genius through the centuries. London: David Harvey Publishers.

Панонски легенди. (1969). Скопје: Македонска книга.

Панонски легенди. (1987). Скопје: Наша книга, Македонска книга, Мисла и Култура.

Поленаковиќ, Х. (1985). Творц̧ите на словенската писменост. Скопје: Мисла.

Поповски, А. (1989). „Климент Охридски и филозофско-хуманистичките аспекти на киридо-методиевската традиција и иницијативи“, во: Климент Охридски и улогата на Охридската книжевна икола во развитокот на словенската просвета, МАНУ: Скопје.

Spinka, M. (1968). A History of Christianity in the Balkans. Hamden, Connecticut: Archon Books.

Свидлер, А. \& П. Мојзес. (2005). Изучуватьето на религијата во ерата на глобалниот дијалог. Скопје: Темплум.

Tachiaos, A.-E. N. (2001). Cyril and Methodius of Thessalonica: The Acculturation of the Slavs. Yonkers, New York: St. Vladimir's Seminary Press.

Темков, К. (2003). „Свети Кирид Филозоф - посветеност кон воздигнување на луѓето“, во: СТАРТ, бр. 212, Скопје.

Топенчаров, В. (1970). Константин-Кирил Филозоф А Б В на ренесансата. Народна младеж.

Велев, И. (2005). Византиско-македонски книжевни врски. Скопје: САМОИЗДАТ. 